\title{
Daya Saing dan Faktor-Faktor yang Mempengaruhi Ekspor Nanas Indonesia
}

\author{
Competitiveness and the Factors Affecting Indonesian Pineapple Exports \\ Viola Rachma Safitri ${ }^{1}$ dan Fitri Kartiasih ${ }^{2 *}$
}

Diterima 03 Januari 2019/Disetujui 25 Maret 2019

\begin{abstract}
This study aims to determine the general picture of pineapple production and export in Indonesia, analyze the competitiveness of Indonesian pineapple in seven main export destination countries, and analyze the factors that affect Indonesian pineapple exports in the main export destination of pineapple in 2001-2014. The methods used in this study are Revealed Comparative Advantage (RCA), Trade Specialization Index (ISP), Intra-Industry Trade (IIT), and panel data regression. The results of this study indicate that the high production of Indonesian pineapple has not been matched by an increase in the volume of pineapple exports. The RCA index shows that Indonesia is superior to the Philippines in several countries such as the Netherlands, Germany, Singapore, Spain and Argentina for pineapple commodities. The ISP and IIT indices show that Indonesia has a tendency as an exporting country. The variable competitiveness index, the real exchange rate of the rupiah against the destination country currency, the income per capita of the destination country, and the amount of Indonesian pineapple production have a positive influence on the growth of the volume of pineapple exports in the seven main export destination countries while the price of pineapple real exports has a negative influence on the volume of pineapple exports in the seven main export destination countries.
\end{abstract}

Keywords: competitiveness, panel data, pineapple exports, $R C A$

\begin{abstract}
ABSTRAK
Penelitian ini bertujuan untuk mengetahui gambaran umum produksi dan ekspor nanas di Indonesia, menganalisis daya saing nanas Indonesia di tujuh negara tujuan ekspor utama, dan menganalisis faktor-faktor yang mepengaruhi ekspor nanas Indonesia di negara tujuan ekspor utama nanas tahun 2001-2014. Metode yang digunakan dalam penelitian ini adalah Revealed Comparative Advantage (RCA), Indeks Spesialisasi Perdagangan (ISP), Intra Industry Trade (IIT), dan regresi data panel. Hasil penelitian ini menunjukkan bahwa tingginya produksi nanas Indonesia belum diimbangi dengan peningkatan volume ekspor nanas. Indeks RCA menunjukkan bahwa Indonesia lebih unggul dibandingkan Filipina di beberapa negara seperti Belanda, Jerman, Singapura, Spanyol, dan Argentina untuk komoditi nanas. Indeks ISP dan IIT menunjukkan bahwa Indonesia memiliki kecenderungan sebagai negara eksportir. Variabel indeks daya saing, nilai tukar riil rupiah terhadap mata uang negara tujuan, pendapatan per kapita negara tujuan, serta jumlah produksi nanas Indonesia memiliki pengaruh positif terhadap pertumbuhan volume ekspor nanas di ketujuh negara tujuan ekspor utama sedangkan harga ekspor riil nanas memiliki pengaruh yang negatif terhadap volume ekspor nanas di ketujuh negara tujuan ekspor utama.
\end{abstract}

Kata Kunci: data panel, daya saing, ekspor nanas, RCA

\footnotetext{
${ }^{1}$ BPS Kabupaten Tanah Bumbu, J1. Dharma Praja Komp. Perkantoran Gunung Tinggi 72211

${ }^{2}$ Politeknik Statistika STIS, Jl. Otista No.64C, Jakarta 13330.

E-mail : fkartiasih@stis.ac.id (*Penulis korespondensi)
} 


\section{PENDAHULUAN}

Sektor pertanian merupakan sektor ekonomi potensial yang berkontribusi dalam pembentukan ekonomi nasional. Sektor pertanian, peternakan, kehutanan, dan perikanan memberikan kontribusi lebih dari $15 \%$ pada PDB non migas Indonesia sejak tahun 20012014, dengan jumlah terbesar berasal dari tanaman bahan makanan. Komoditas tanaman bahan makanan memberi sumbangan lebih dari $50 \%$ dan terus mengalami peningkatan yang signifikan. Neraca perdagangan pada tahun 2014 untuk komoditas pertanian sempat mengalami defisit hingga mencapai minus USD 15.87. Hal ini disebabkan oleh tingginya impor pada sektor tanaman pangan di Indonesia. Berdasarkan nilai impor komoditas pertanian pada tahun 2014, kontribusi impor subsektor tanaman pangan menduduki peringkat pertama terhadap total impor komoditas pertanian, yakni sebesar 48.27\%. Posisi berikutnya adalah kontribusi impor subsektor perternakan sebesar $23.95 \%$, subsektor perkebunan sebesar $17.50 \%$. Kontribusi terkecil adalah dari impor komoditas hortikultura sebesar $10.29 \%$ (Kementerian Pertanian, 2015).

Dalam kondisi rendahnya neraca perdagangan subsektor tanaman pangan dalam sektor pertanian, beberapa komoditi dalam subsektor hortikultura justru mengalami surplus serta peningkatan produksi. Nanas (Ananas comosus L.) adalah salah satu komoditas buah unggulan di Indonesia. Pemanfaatan nanas bisa bermacam-macam, selain untuk konsumsi buah segar (fresh fruit), hasil buah untuk bahan juice, maupun bagian buah, daun, atau bagian lainnya untuk massage/spa (Rai et al., 2016). Buah nanas menempati urutan keempat produksi tertinggi dalam komoditas buah-buahan Indonesia setelah pisang, mangga, dan jeruk siam. Selain itu nanas secara konstan memberikan surplus dengan neraca perdagangan yang terus meningkat dari 63.53 juta USD pada 2001 menjadi 192.99 juta USD pada 2014 (Kementerian Pertanian, 2015).

Secara keseluruhan neraca perdagangan untuk komoditi nanas terus mengalami surplus, namun ternyata Indonesia belum memaksimalkan potensi produksi yang dimiliki. Berdasarkan Gambar 1 dan Gambar 2, produksi nanas terus mengalami peningkatan dari 494.97 ribu ton pada tahun 2001 hingga mencapai 1.83 juta ton pada 2014. Namun volume ekspor nanas segar justru mengalami penurunan dalam 15 tahun, begitu pula dengan volume ekspor nanas olahan yang cenderung konstan. Bahkan rasio volume ekspor terhadap produksi terus menurun. Volume ekspor nanas yang awalnya $38.69 \%$ dari total produksi pada 2001 menurun hingga $10.48 \%$ pada 2014.

Buah nanas merupakan salah satu tropical fruit yang menjadi primadona di luar negeri terutama negara non-tropis seperti Amerika, Jerman, Rusia, Spanyol, Belanda, dan lainnya (Kementerian Pertanian, 2015). Namun di Indonesia sendiri, nanas justru kurang begitu diminati. Hal ini ditunjukkan dengan konsumsi per kapita di Indonesia untuk komoditi nanas yang terus menurun. Dalam seminggu konsumsi per kapita nanas di tahun 2000 adalah 0.469 dan meningkat di tahun 2005 menjadi 0.574. Namun saat ini konsumsi nanas per kapita dalam seminggu hanyalah 0.215 (Kementerian Pertanian, 2015). Hal ini menunjukkan bahwa Indonesia belum mengoptimalkan potensi ekspor dari tingginya produksi nanas domestik. Nanas sebagai komoditi ekspor dengan produksi yang potensial, seharusnya mampu memberikan kontribusi yang tinggi pada nilai ekspor hortikultura. Menurut Nasution et al. (2010) panjang buah, diameter buah dan jumlah spiral dapat dijadikan seleksi untuk mendapatkan nanas dengan bobot buah yang tinggi, sehingga produksi nanas bisa ditingkatkan.

Ekspor merupakan kegiatan dalam perdagangan internasional yaitu melakukan aktivitas penjualan produk ke luar negeri dengan tujuan memperoleh keuntungan. Terdapat beberapa faktor yang berpengaruh seperti kebijakan pemerintah akan perdagangan luar negeri, keadaan pasar di luar negeri, kelincahan eksportir dalam memanfaatkan peluang pasar (Ekananda, 2014).

Beberapa penelitian mengenai daya saing ekspor nanas dan buah-buahan pernah dilakukan oleh Suntharalingam et al. (2011), Thamiem et al. (2011), Whitfield (2012), Adegbite et al. (2014), Boansi (2014), Chaitip dan Dewitt (2015), serta Rozana et al. (2017). Penelitian tentang ekspor nanas segar Indonesia oleh Istiqomah (2008) menemukan bahwa variabel produksi, harga ekspor dan nilai tukar berpengaruh signifikan terhadap volume ekspor Indonesia. Karomah (2011) menggunakan indeks RCA, EPD, dan IIT untuk melihat daya saing nanas segar Indonesia. 


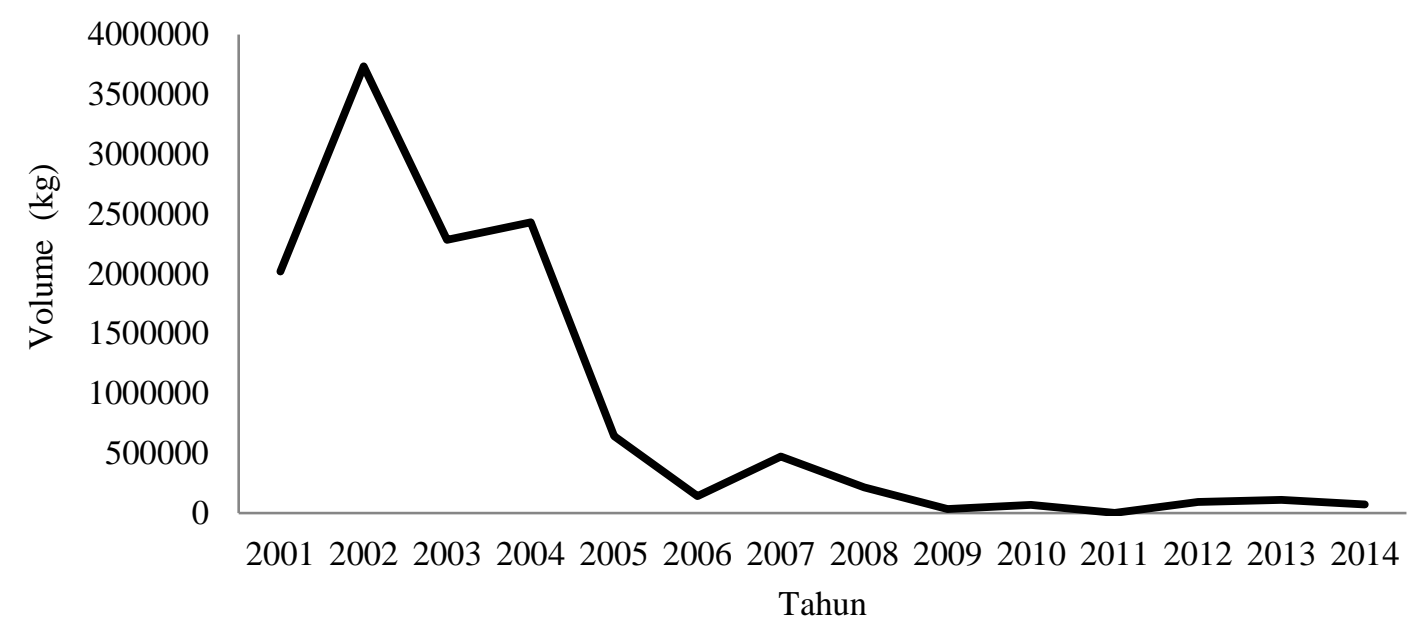

Keterangan: Sumber BPS, diolah

Gambar 1. Volume ekspor nanas segar Indonesia ke pasar dunia tahun 2001-2014

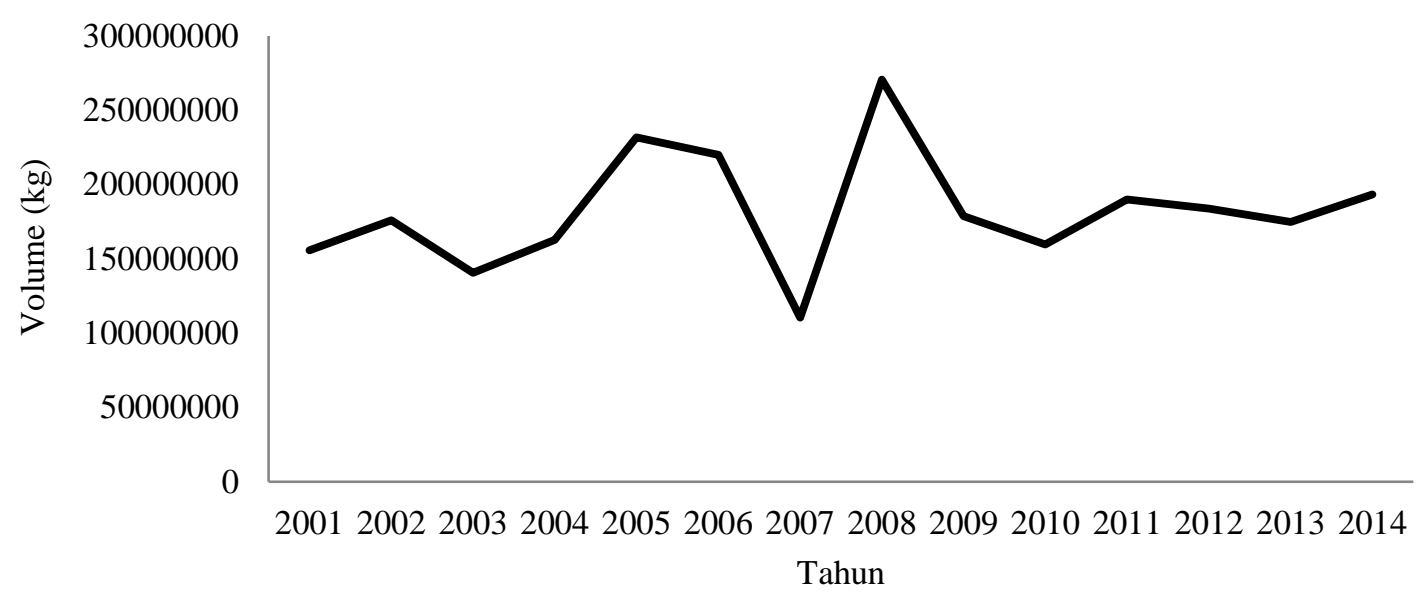

Keterangan: Sumber BPS, diolah

Gambar 2. Volume ekspor nanas olahan Indonesia ke pasar dunia tahun 2001-2014

Hipotesis dalam penelitian ini adalah bahwa tingkat daya saing (RCA), pendapatan per kapita negara tujuan, nilai tukar rupiah di negara tujuan, dan produksi nanas domestik memiliki pengaruh yang positif dan signifikan terhadap volume ekspor sedangkan harga ekspor nanas di negara tujuan memiliki pengaruh negatif dan signifikan terhadap volume ekspor.

Terkait dengan masalah-masalah di atas, maka penelitian ini bertujuan untuk: 1) mengetahui gambaran umum ekspor nanas di Indonesia tahun 2001-2014; 2) menganalisis daya saing nanas olahan Indonesia di tujuh negara tujuan ekspor utama tahun 2001-2014; dan 3) menganalisis faktor yang memengaruhi ekspor nanas Indonesia di negara tujuan ekspor utama nanas Indonesia tahun 2001-2014.

\section{BAHAN DAN METODE}

Penelitian ini menggunakan analisis regresi data panel untuk 7 negara tujuan ekspor utama komoditi nanas Indonesia yaitu Amerika Serikat, Argentina, Belanda, Jepang, Jerman, Singapura, dan Spanyol. Data sekunder yang digunakan bersumber dari BPS, UN Comtrade, $I M F$, dan Worldbank.

Komoditi yang digunakan dalam penelitian ini adalah produk nanas dengan kode Harmonizing System (HS) 6 digit yaitu 080430, 200820, 200940, 200941, dan 200949 (Tabel 2). 
Tabel 1. Jenis dan Sumber Data

\begin{tabular}{|c|c|}
\hline Jenis Data & Sumber Data \\
\hline $\begin{array}{l}\text { Volume ekspor (ton) dan nilai ekspor (ribu } \\
\text { USD) nanas Indonesia }\end{array}$ & Badan Pusat Statistik \\
\hline $\begin{array}{l}\text { Volume ekspor (ton) nanas Indonesia ke tujuh } \\
\text { negara tujuan ekspor utama }\end{array}$ & $\begin{array}{l}\text { United Nation Commodity Trade Statistic } \\
\text { Division (UN Comtrade) }\end{array}$ \\
\hline $\begin{array}{l}\text { Total nilai ekspor Indonesia, Thailand, dan } \\
\text { Filipina (ribu USD), serta total nilai ekspor } \\
\text { dunia (ribu USD) untuk komoditi nanas ke tujuh } \\
\text { negara tujuan ekspor utama }\end{array}$ & $\begin{array}{l}\text { United Nation Commodity Trade Statistic } \\
\text { Division (UN Comtrade) }\end{array}$ \\
\hline Produksi nanas Indonesia & Badan Pusat Statistik \\
\hline IHPB Ekspor Indonesia tahun dasar 2005 & Badan Pusat Statistik \\
\hline Konsumsi nanas per kapita & Badan Pusat Statistik \\
\hline $\begin{array}{l}\text { GDP per kapita ADHK }(2005=100)(\text { USD) } 7 \\
\text { negara tujuan ekspor utama }\end{array}$ & World Bank \\
\hline Kurs riil (average of period) Indonesia terhadap & International Financial Statistics (IFS) \\
\hline 7 negara tujuan ekspor utama & IMF \\
\hline
\end{tabular}

Tabel 2. Daftar Kode HS Komoditi Nanas

\begin{tabular}{cl}
\hline Kode HS & \\
\hline 080430 & Pineapples, fresh or dried \\
200820 & Pineapples nes, o/w prepared or preserved, sugared, sweetened, spirited or not \\
200940 & Pineapple juice, unfermented, spirited, whether or not sugard or sweet \\
200941 & Pineapple juice, unfermented, Brix value $<=20$ at $20^{\circ} \mathrm{C}$, whether or not \\
200949 & Pineapple juice, unfermented, Brix value $>20$ at $20^{\circ} \mathrm{C}$, whether or not \\
\hline Keterangan: Sumber $U N$ Comtrade
\end{tabular}
Keterangan: Sumber UN Comtrade

Analisis deskriptif berupa grafik digunakan untuk menunjukkan produksi dan kinerja ekspor nanas. Indeks RCA, ISP, dan IIT digunakan untuk mengukur daya saing nanas. Ketiga indeks tersebut dirumuskan sebagai berikut:

$R C A_{i j}=\frac{X_{i j} / X_{i t}}{W_{j} / W_{t}} ;$ dengan $X_{i j}$ adalah nilai ekspor komoditas $\mathrm{j}$ dari negara $\mathrm{i}, X_{i t}$ adalah nilai ekspor total produk (komoditas $\mathrm{j}$ dan lainnya) negara $\mathrm{i}, W_{j}$ adalah nilai ekspor komoditas $\mathrm{j}$ di dunia, dan $W_{t}$ adalah nilai ekspor total dunia (Tambunan, 2000).

$I S P=\frac{X_{i j}-M_{i j}}{X_{i j}+M_{i j}}$; dengan $X_{i j}$ adalah nilai ekspor komoditas i dari negara $\mathrm{j}$ dan $M_{i j}$ adalah nilai impor komoditas $\mathrm{i}$ dari negara $\mathrm{j}$ (Tambunan, 2000).

$I I T=1-\frac{X-M}{X+M} \times 100$, dengan $\mathrm{X}$ adalah nilai ekspor dan $\mathrm{M}$ adalah nilai impor (Grubel dan Lloyd, 1975).

Sementara itu, untuk menjawab tujuan ketiga dilakukan analisis regresi data panel dengan melakukan beberapa uji sebelum menentukan model terbaik. Model yang terpilih dalam penelitian ini adalah fixed effects model dengan cross section weights-Seemingly Unrelated Regression dengan bentuk model sebagai berikut:

$$
\begin{aligned}
\ln E X P_{i t}=\alpha+ & \beta_{1} \ln R C A_{i t}+\beta_{2} \ln G D P_{i t} \\
& +\beta_{3} \ln R P R O D_{t} \\
& +\beta_{4} \ln E R \_R I I L_{i t} \\
& -\beta_{5} \ln P R I C E_{-} R I I L_{i t}+\varepsilon_{i t}
\end{aligned}
$$

Dimana adalah ekspor nanas Indonesia ke tujuh negara tujuan utama, RCA adalah tingkat daya saing nanas, GDP adalah pendapatan per kapita negara tujuan, PROD adalah jumlah produksi nanas Indonesia, ER_RIIL adalah nilai tukar riil rupiah terhadap mata uang negara tujuan, dan PRICE_RIIL adalah harga riil ekspor nanas di negara tujuan.

\section{HASIL DAN PEMBAHASAN}

\section{Gambaran Umum Ekspor Nanas Indonesia ke Tujuh Negara Tujuan Ekspor Utama}

Nanas dengan kode HS 080430, 200820, 200940, 200941, dan 200949 merupakan salah satu komoditi unggulan pada sub sektor hortikultura yang secara konstan memberikan 
surplus dalam neraca perdagangan. Namun volume ekspor nanas Indonesia selama 20012014 memang belum mengimbangi peningkatan tajam pada produksi nanas dalam negeri (Gambar 3).

Berdasarkan Gambar 4 dapat dilihat bahwa negara tujuan ekspor utama nanas Indonesia adalah Amerika Serikat, Belanda, Jepang, Jerman, Singapura, Spanyol, dan Argentina dengan total kontribusi $76.72 \%$ dari seluruh ekspor nanas Indonesia ke dunia.

Ekspor nanas Indonesia secara keseluruhan cenderung konstan selama periode 2001-2014, dengan Amerika Serikat yang secara kontinyu menjadi negara tujuan ekspor utama. Perkembangan volume ekspor nanas Indonesia menurut negara tujuan pada Gambar
5 menunjukkan bahwa pada tahun 2006 ke 2007 telah terjadi penurunan ekspor nanas di ketujuh negara. Krisis global yang terjadi pada tahun tersebut memang cukup berpengaruh pada perdagangan internasional yang berkaitan dengan pembatasan impor.

Beberapa negara tujuan utama ekspor nanas Indonesia yang juga merupakan negara importir nanas utama di dunia yaitu Amerika Serikat, Jerman, Spanyol, Belanda, dan Jepang. Singapura juga merupakan negara importir utama untuk komoditi nanas olahan di ASEAN. Hal ini menunjukkan bahwa persaingan pasar nanas di negara-negara tersebut akan semakin sulit. Karena negara produsen utama lain seperti Costa Rica, Brazil, Filipina, dan Thailand juga akan bersaing di pasar tersebut.

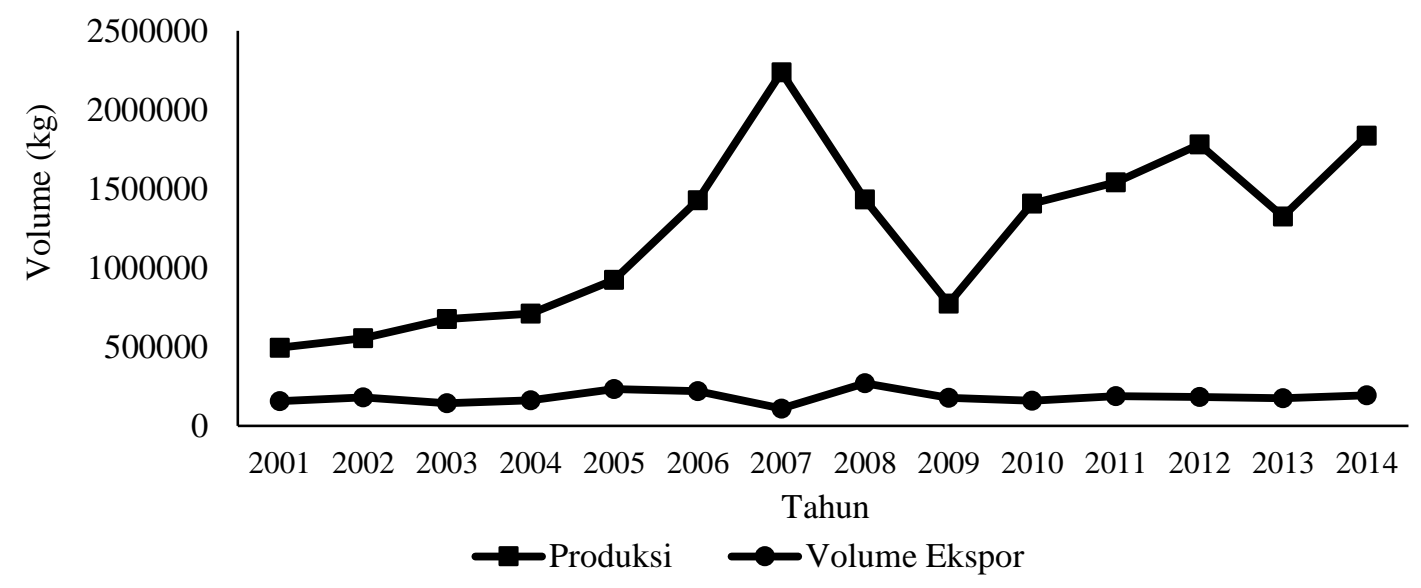

Keterangan: Sumber BPS, diolah

Gambar 3. Volume produksi dan ekspor nanas Indonesia tahun 2001-2014 (ton)

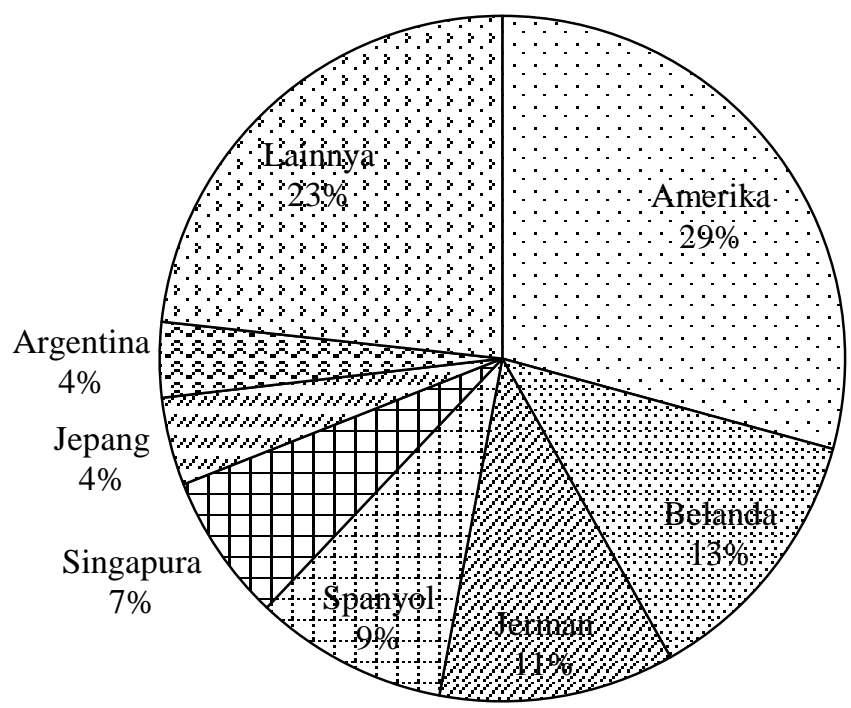

Keterangan: Sumber UN Comtrade, diolah

Gambar 4. Persentase ekspor nanas Indonesia ke negara tujuan utama 


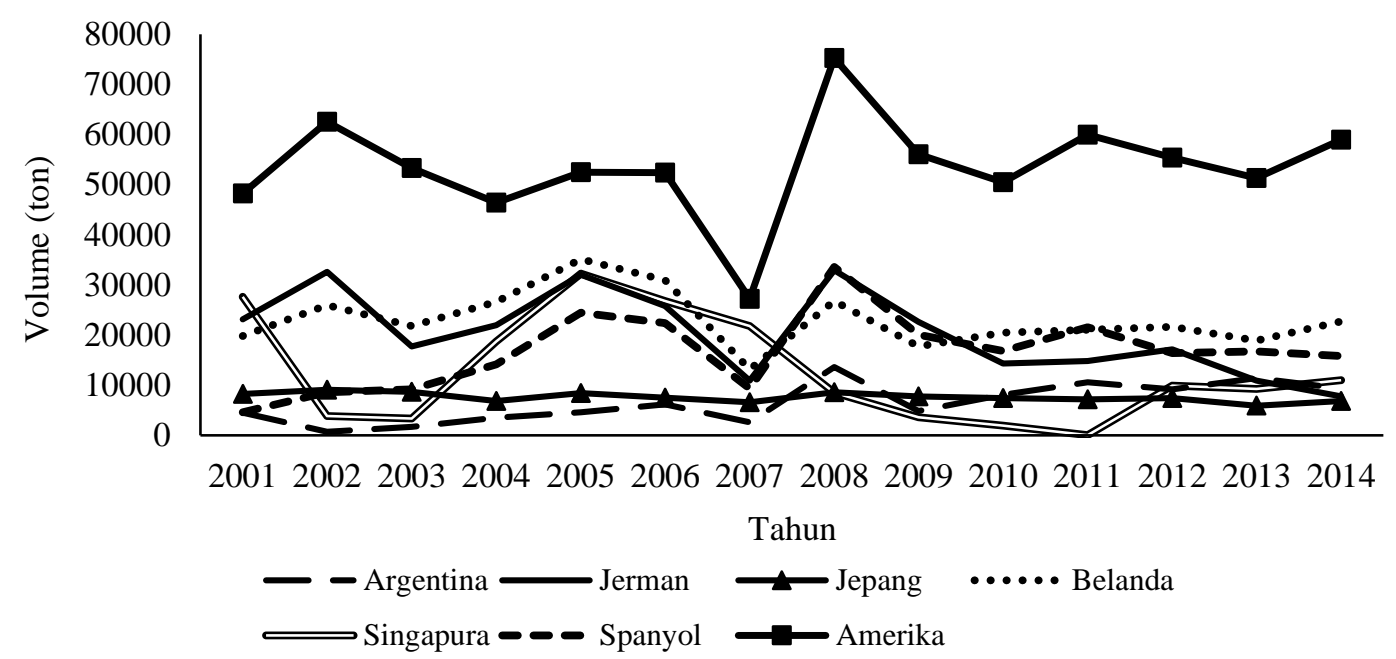

Keterangan: Sumber UN Comtrade, diolah

Gambar 5. Volume ekspor nanas Indonesia di tujuh negara tujuan utama ekspor tahun 2001-2014.

\section{Daya Saing Nanas Indonesia di Tujuh Negara Tujuan Ekspor Utama}

Komoditi nanas Indonesia diekspor dalam berbagai bentuk mulai dari nanas segar, nanas kaleng, selai, serta jus. Untuk melihat posisi daya saing produk nanas Indonesia secara total baik nanas segar maupun olahan nanas, maka dilakukan juga perbandingan dengan negara pesaing lainnya yaitu Thailand dan Filipina yang memiliki volume ekspor lebih besar dari Indonesia. Perkembangan indeks RCA di ketujuh pasar utama ekspor seperti yang terlihat pada Gambar 6 menunjukkan bahwa Indonesia memiliki daya saing pada komoditi nanas dengan nilai RCA lebih dari 1 .

Berdasarkan analisis daya saing nanas Indonesia di tujuh negara tujuan utama ekspor pada tahun 2001-2014, dapat dilihat bahwa Indonesia lebih unggul dibandingkan Filipina di beberapa negara seperti Belanda, Jerman, Singapura, Spanyol, dan Argentina untuk komoditi nanas. Bahkan nanas Indonesia mampu mengungguli Thailand, sebagai eksportir utama dunia, di beberapa negara yaitu Singapura dan Argentina. Hal ini menunjukkan bahwa Indonesia masih memiliki peluang untuk meningkatkan volume ekspor nanas pada negara tujuan ekspor utama tersebut. Daya saing nanas Indonesia relatif lemah di pasar Amerika Serikat dan Jepang sehingga ekspor nanas di kedua negara tersebut harus ditingkatkan. Karena Amerika Serikat dan Jepang merupakan negara importir nanas terbesar di dunia, sehingga Indonesia juga dapat meningkatkan ekspor nanas secara agregat.

Selain menggunakan indeks RCA, indeks lain seperti ISP yang ditunjukkan oleh Tabel 3 dan IIT (dapat dilihat pada Tabel 4) menunjukkan hasil yang sejalan. ISP yang bernilai mendekati 1 menunjukkan bahwa Indonesia memiliki spesialisasi untuk komoditi nanas dan cenderung menjadi negara eksportir pada komoditi tersebut. Indeks IIT berada pada daerah "integrasi lemah", artinya hanya terdapat aliran perdagangan satu arah yaitu Indonesia ke tujuh negara tujuan ekspor utama selama periode 2001-2014.

Analisis Variabel-Variabel yang Memengaruhi Ekspor Nanas Indonesia ke Tujuh Negara Tujuan Ekspor Utama Tahun 2001-2014

Model regresi data panel untuk menjelaskan pengaruh kelima variabel bebas terhadap volume ekspor nanas Indonesia tahun 2001-2014 yang terpilih adalah Fixed Effects Model with Cross Section Weight-Seemingly Unrelated Regression dengan persamaan sebagai berikut:

\footnotetext{
$\ln \widehat{\operatorname{EXP}}_{\text {it }}=(-8.15+\alpha)^{*}+1.00 \operatorname{lnRCA}{ }_{i t}{ }^{*}+$ $1.50 \operatorname{lnGDP}_{\mathrm{it}} *+0.16 \operatorname{lnPROD}_{\mathrm{t}} *+$ 0.211 nER_RIIL ${ }_{\mathrm{it}}{ }^{*}$ 0.611 PRICE_RIIL ${ }_{\mathrm{it}}$ *

Keterangan: *signifikan pada tingkat signifikansi 5\%, dengan $A d j-\mathrm{R}^{2}=98.97 \%$ dan F-statistic $=851.08$.
} 

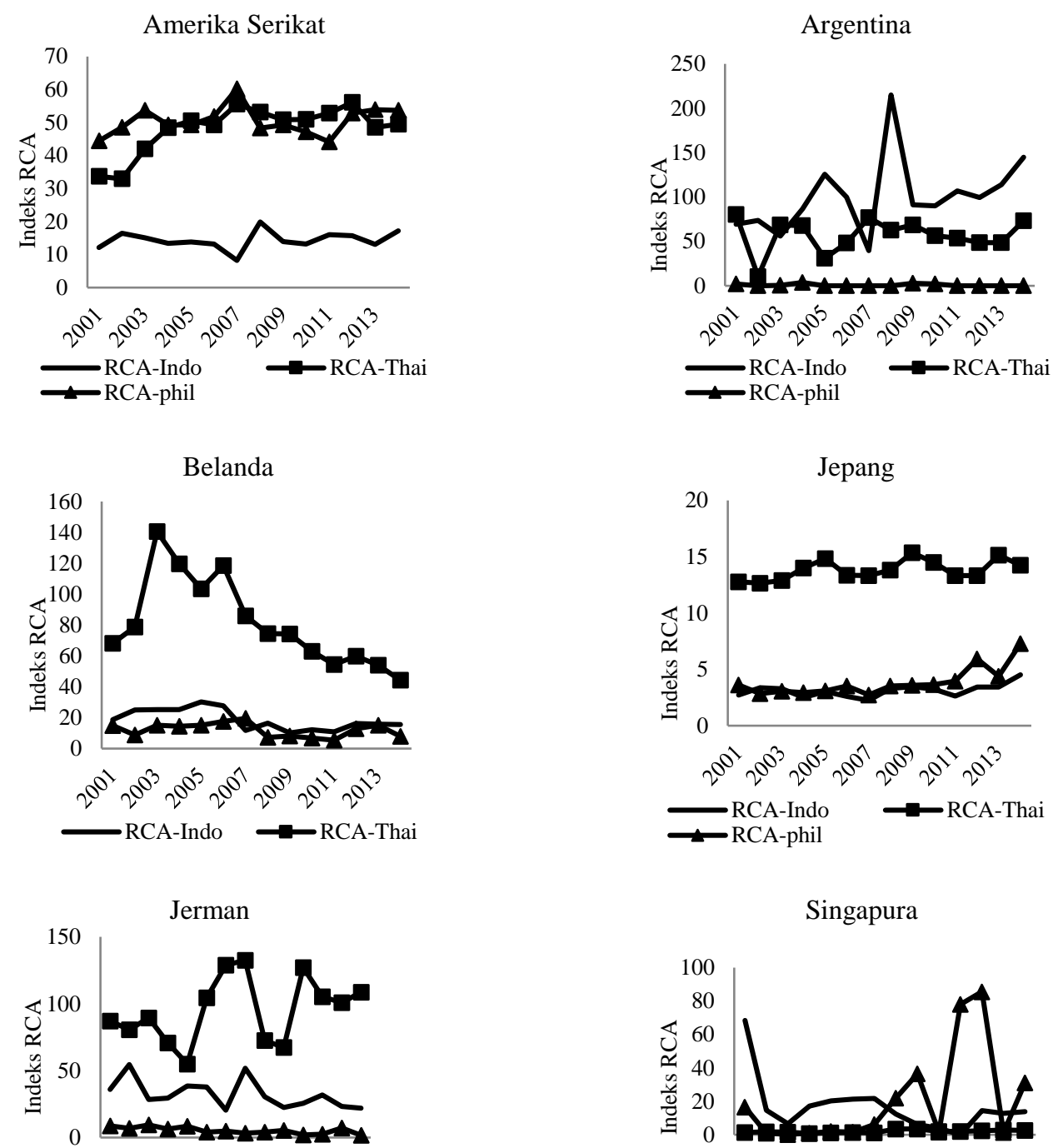

Singapura

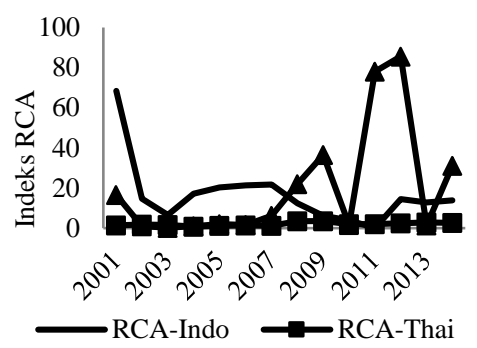

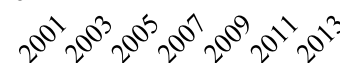

$\longrightarrow$ RCA-Indo $\rightarrow$ RCA-Thai

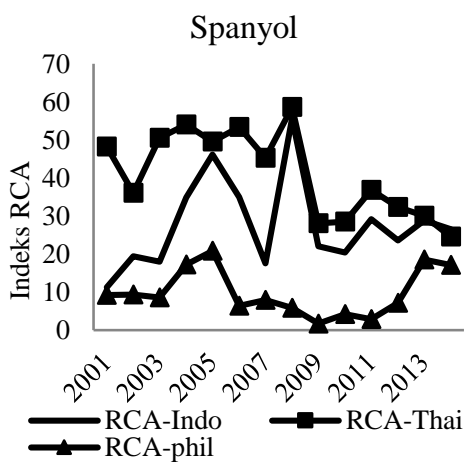

Keterangan: Sumber UN Comtrade, diolah

Gambar 6. Revealed Comparative Advantage Indonesia, Thailand, dan Filipina komoditi nanas segar dan olahan. 
Tabel 3. Indeks spesialisasi perdagangan nanas Indonesia di tujuh negara tujuan ekspor utama tahun 2001-2014

\begin{tabular}{cccccccc}
\hline \multirow{2}{*}{ Tahun } & \multicolumn{7}{c}{ Negara Tujuan Utama } \\
\cline { 2 - 7 } & AS & Argentina & Belanda & Jerman & Jepang & Singapura & Spanyol \\
\hline 2001 & 0.9979 & 1.0000 & 1.0000 & 1.0000 & 1.0000 & 0.9781 & 1.0000 \\
2002 & 0.9993 & 1.0000 & 1.0000 & 1.0000 & 1.0000 & 0.9702 & 1.0000 \\
2003 & 0.9996 & 1.0000 & 1.0000 & 1.0000 & 0.9962 & 0.9802 & 1.0000 \\
2004 & 0.9994 & 1.0000 & 1.0000 & 1.0000 & 1.0000 & 0.9966 & 1.0000 \\
2005 & 0.9993 & 1.0000 & 0.9994 & 0.9979 & 1.0000 & 0.9968 & 1.0000 \\
2006 & 0.9988 & 1.0000 & 1.0000 & 1.0000 & 1.0000 & 0.9967 & 1.0000 \\
2007 & 0.9977 & 1.0000 & 1.0000 & 1.0000 & 1.0000 & 0.9961 & 1.0000 \\
2008 & 0.9995 & 1.0000 & 1.0000 & 1.0000 & 0.9983 & 0.9914 & 1.0000 \\
2009 & 1.0000 & 1.0000 & 1.0000 & 1.0000 & 1.0000 & 0.9626 & 1.0000 \\
2010 & 1.0000 & 1.0000 & 1.0000 & 1.0000 & 1.0000 & 0.9671 & 1.0000 \\
2011 & 1.0000 & 1.0000 & 1.0000 & 1.0000 & 1.0000 & 0.1743 & 1.0000 \\
2012 & 1.0000 & 1.0000 & 1.0000 & 1.0000 & 1.0000 & 0.9808 & 1.0000 \\
2013 & 1.0000 & 1.0000 & 1.0000 & 1.0000 & 1.0000 & 1.0000 & 1.0000 \\
2014 & 1.0000 & 1.0000 & 0.9997 & 1.0000 & 1.0000 & 1.0000 & 1.0000 \\
\hline
\end{tabular}

Keterangan: Sumber: UN Comtrade, diolah.

Tabel 4. Intra Industry Trade nanas Indonesia di tujuh negara tujuan ekspor utama tahun 2001-2014

\begin{tabular}{ccccccrc}
\hline \multirow{2}{*}{ Tahun } & \multicolumn{7}{c}{ Negara Tujuan Utama } \\
\cline { 2 - 7 } & AS & Argentina & Belanda & Jerman & Jepang & Singapura & Spanyol \\
\hline 2001 & 0.210 & 0.0000 & 0.0000 & 0.0000 & 0.0000 & 2.1882 & 0.0000 \\
2002 & 0.0707 & 0.0000 & 0.0000 & 0.0000 & 0.0000 & 2.9795 & 0.0000 \\
2003 & 0.0384 & 0.0000 & 0.0000 & 0.0000 & 0.3755 & 1.9762 & 0.0000 \\
2004 & 0.0647 & 0.0000 & 0.0000 & 0.0000 & 0.0000 & 0.3389 & 0.0000 \\
2005 & 0.0704 & 0.0000 & 0.0608 & 0.2136 & 0.0000 & 0.3182 & 0.0000 \\
2006 & 0.1195 & 0.0000 & 0.0000 & 0.0000 & 0.0000 & 0.3281 & 0.0000 \\
2007 & 0.2305 & 0.0000 & 0.0000 & 0.0000 & 0.0000 & 0.3925 & 0.0000 \\
2008 & 0.0495 & 0.0000 & 0.0000 & 0.0000 & 0.1720 & 0.8614 & 0.0000 \\
2009 & 0.0000 & 0.0000 & 0.0000 & 0.0000 & 0.0000 & 3.7404 & 0.0000 \\
2010 & 0.0000 & 0.0000 & 0.0000 & 0.0000 & 0.0000 & 3.2885 & 0.0000 \\
2011 & 0.0000 & 0.0000 & 0.0000 & 0.0000 & 0.0000 & 82.5688 & 0.0000 \\
2012 & 0.0000 & 0.0000 & 0.0000 & 0.0000 & 0.0000 & 1.9212 & 0.0000 \\
2013 & 0.0000 & 0.0000 & 0.0000 & 0.0000 & 0.0000 & 0.0000 & 0.0000 \\
2014 & 0.0000 & 0.0000 & 0.0279 & 0.0000 & 0.0000 & 0.0000 & 0.0000 \\
\hline
\end{tabular}

Keterangan: Sumber: UN Comtrade, diolah

Persamaan tersebut telah memenuhi asumsi klasik yaitu normalitas dan multikolinieritas. Nilai intersep signifikan menunjukkan adanya pengaruh individu, yaitu negara tujuan utama ekspor. Nilai intersep tertinggi yang dimiliki oleh Jepang menunjukkan bahwa saat semua variabel bebas konstan, volume ekspor tertinggi adalah ke Jepang. Sebaliknya nilai intersep terkecil ditunjukkan oleh Jerman. Sehingga saat variabel bebas dianggap konstan, Jerman akan menjadi pengimpor nanas Indonesia terkecil.

Negara yang memiliki faktor produksi berlimpah dan lebih murah akan cenderung melakukan ekspor, sebaliknya negara yang memiliki faktor produksi langka serta lebih mahal akan cenderung melakukan impor (Salvatore, 2016). Indeks RCA menggambarkan efektivitas suatu negara dalam memproduksi suatu komoditi. Negara dengan nilai RCA lebih tinggi dibandingkan negara lain menunjukkan bahwa negara tersebut mampu memproduksi komoditi dengan lebih efektif. RCA juga menunjukkan posisi daya saing suatu negara dibandingkan negara lain. Tingkat daya saing suatu negara untuk komoditi tertentu akan memiliki pengaruh positif terhadap volume ekspor untuk komoditi tersebut. 
Hasil estimasi variabel indeks RCA dalam penelitian ini berpengaruh positif dan signifikan terhadap volume ekspor nanas Indonesia di tujuh negara tujuan ekspor pada tingkat signifikansi 5\%. Hal ini sesuai dengan penelitian Boansi et al. (2014). Jika terjadi peningkatan $1 \%$ indeks daya saing RCA, maka volume ekspor nanas di tujuh negara tujuan utama ekspor akan meningkat sebesar $1 \%$ dengan asumsi variabel-variabel bebas lainnya konstan.

Hasil estimasi regresi data panel juga menunjukkan bahwa variabel pendapatan per kapita negara tujuan ekspor memiliki pengaruh positif dan signifikan terhadap pertumbuhan volume ekspor nanas Indonesia ke tujuh negara tujuan ekspor pada taraf nyata $5 \%$. Hal ini sesuai dengan teori bahwa dengan asumsi faktor lain tetap, saat terjadi kenaikan pendapatan luar negeri akan berakibat pada kenaikan jumlah permintaan barang dan jasa (Lipsey, 1995). Jika pendapatan per kapita negara tujuan ekspor meningkat sebesar $1 \%$, maka volume ekspor nanas di tujuh negara tujuan utama ekspor akan meningkat sebesar $1.50 \%$ dengan asumsi variabel-variabel bebas lainnya konstan. Hasil penelitian ini sejalan dengan penelitian Karomah (2011) mengenai ekspor komoditi nanas segar yang menemukan bahwa pendapatan per kapita negara tujuan ekspor signifikan memiliki pengaruh positif terhadap volume ekspor nanas segar.

Ekspor dan produksi secara teoritis memiliki hubungan dua arah. Peningkatan permintaan dunia terhadap produk-produk dapat memberi dorongan positif terhadap peningkatan produksi dalam negeri. Namun di sisi lain, adanya peningkatan produksi dapat memicu terjadinya ekspor. Pada tingkat produksi tertentu terdapat kemungkinan negara tidak dapat memenuhi kebutuhan ekspor, namun pada tingkat produksi yang tinggi akan memberi kesempatan untuk suatu negara melakukan ekspor (Tambunan, 2000).

Sejalan dengan penelitian Istiqomah (2008) tentang ekspor nanas segar Indonesia ke Malaysia, bahwa variabel produksi nanas domestik memiliki pengaruh positif dan sigifikan terhadap volume ekspor. Hasil estimasi menunjukkan bahwa variabel produksi nanas Indonesia memiliki pengaruh positif dan signifikan terhadap volume ekspor nanas Indonesia oleh tujuh negara tujuan ekspor pada $\alpha=5 \%$. Artinya saat terjadi peningkatan $1 \%$ jumlah produksi nanas dalam negeri, maka volume ekspor nanas di tujuh negara tujuan utama ekspor akan meningkat sebesar $0.16 \%$ dengan asumsi variabel-variabel bebas lainnya konstan.

Nilai tukar riil menggambarkan perbandingan harga komoditi nanas di Indonesia serta di negara tujuan ekspor. Hal ini menunjukkan bahwa saat kurs rupiah terhadap negara tujuan naik atau terjadi depresiasi nilai rupiah, maka harga nanas Indonesia akan lebih murah dibandingkan harga nanas di negara tujuan. Permintaan ekspor oleh negara tersebut terhadap Indonesia akan meningkat.

Koefisien untuk variabel nilai tukar riil menunjukkan pengaruh positif dan signifikan terhadap volume ekspor nanas. Hal ini sejalan dengan penelitian Istiqomah (2008) yang menunjukkan bahwa nilai tukar rupiah memiliki pengaruh positif terhadap permintaan ekspor nanas segar Indonesia. Saat harga mata uang rupiah terdepresiasi sebesar $1 \%$ di tujuh negara tujuan ekspor utama maka daya beli konsumen akan produk nanas akan meningkat sehingga volume ekspor nanas di tujuh negara tujuan utama ekspor juga akan meningkat sebesar $0.21 \%$ dengan asumsi variabel-variabel bebas lainnya konstan.

Daya beli mempunyai hubungan negatif dengan tingkat harga, artinya saat tingkat harga naik maka kemampuan seseorang untuk membeli suatu barang yang sama akan menurun sebanyak kenaikan tingkat harga. Dalam penelitian ini hasil estimasi variabel harga ekspor riil memiliki pengaruh negatif dan signifikan terhadap volume ekspor nanas Indonesia oleh tujuh negara tujuan ekspor pada taraf nyata 5\%. Hal ini sejalan dengan penelitian Istiqomah (2008). Jika terjadi peningkatan $1 \%$ harga ekspor riil, maka volume ekspor nanas di tujuh negara tujuan utama ekspor akan meningkat sebesar $0.61 \%$ dengan asumsi variabel-variabel bebas lainnya konstan.

\section{KESIMPULAN}

Peningkatan produksi nanas di Indonesia selama tahun 2001-2014 belum diimbangi dengan adanya peningkatan volume ekspor nanas baik dalam bentuk segar maupun olahan, bahkan cenderung terjadi penurunan. Hal ini terjadi karena kurang efisiennya pemanfaatan potensi produksi dalam memenuhi permintaan 
ekspor nanas terutama dalam bentuk olahan. Nanas Indonesia mampu mengungguli Thailand, sebagai eksportir utama nanas olahan di dunia, pada beberapa negara tujuan ekspor yaitu Singapura dan Argentina. Hal ini karena gencarnya promosi produk nanas serta kerjasama bilateral antar kedua negara. Variabel indeks daya saing, nilai tukar riil rupiah terhadap mata uang negara tujuan, pendapatan per kapita negara tujuan, serta jumlah produksi nanas Indonesia memiliki pengaruh positif terhadap volume ekspor nanas di tujuh negara tujuan ekspor utama sedangkan harga ekspor riil nanas memiliki pengaruh yang negatif. Peningkatan pertumbuhan daya saing, pendapatan, produksi, dan nilai tukar riil akan mempercepat pertumbuhan volume ekspor sedangkan peningkatan harga ekspor nanas di negara tujuan ekspor akan menurunkan permintaan ekspor nanas di negara tersebut.

\section{DAFTAR PUSTAKA}

Adegbite, O., O. Oni, I. Adeoye. 2014. Competitiveness of pineapple production in Osun State, Nigeria. J. Economics and Sustainable Development. 5(2): 205-214.

Boansi, D. 2014. Comparative performance of agricultural export trade: during and post-agricultural diversification project in Ghana. British Journal of Economics, Management \& Trade. 4(10): 1501-1511.

Boansi, D., K.O.B. Lokonon, J. Appah. 2014. Determinants of agricultural export trade: case of fresh pineapple exports from Ghana. British J. Economics, Management \& Trade. 4(11): 1736-1754.

[BPS] Badan Pusat Statistik. 2001-2014. Statistik Tanaman Buah-Buahan dan Sayuran Tahunan Indonesia. Jakarta: BPS.

Chaitip, P., C. Chaiboonsri, A. Dewitt. 2015. Canned pineapple in syrup from Thailand export by using panel ARDL method. Procedia Economics and Finance. 24:101-107.

Ekananda, Mahyus. 2014. Ekonomi Internasional. Jakarta: Erlangga.
Grubel, H.G., P.J. Lloyd. 1975. Intra-industry Trade. The Theory and Measurement of International Trade in Differentiated Products. The MacMillan Press Ltd., London.

Istiqomah, A. 2008. Faktor-Faktor yang Mempengaruhi Ekspor Nanas Indonesia ke Malaysia dan Keunggulan Komparatif Nanas Indonesia di Pasar Malaysia. Skripsi. Institut Pertanian Bogor. Bogor.

Karomah, A.B.M. 2011. Analisis Daya Saing dan Faktor-Faktor yang Memengaruhi Aliran Ekspor Nanas Indonesia di Pasar Internasional. Skripsi. Institut Pertanian Bogor. Bogor.

Nasution, M.A., R. Poerwanto, Sobir, M. Surahman, Trikoesoemaningtyas. 2010. Seleksi hasil persilangan antara "queen" dan 'smooth cayenne' untuk perbaikan hasil dan mutu buah nenas. J. Hort. Indonesia. 1(1): 10-16.

[KEMENTAN] Kementerian Pertanian. 2015. Outlook Komoditas Pertanian Subsektor Hortikultura: Nanas. Jakarta: Kementerian Pertanian.

Lipsey, R., Steiner, P.O., Purvis, D.D. 1995. Pengantar Makroekonomi: Edisi Kesepuluh. Jaka Wasana [Penerjemah]. Jakarta: Binarupa Aksara.

Rai, I.N., G. Wijana, I.P. Sudana, I.W. Wiraatmaja, C.G.A. Semarajaya, N.K.A. Astiari. 2016. Identifikasi dan telaah pemanfaatan sumber daya genetik buahbuahan lokal untuk meningkatkan integrasi pertanian dan pariwisata di Bali. J. Hort. Indonesia 7(1): 31-39.

Rozana, N.M.M., C. Suntharalingam, M.F. Othman. 2017. Competitiveness of Malaysia's fruits in the global market: revealed comparative advantage analysis. Malaysian Journal of Mathematical Sciences 11(S): 143-157. 
Salvatore, D. 2016. International Economics, $12^{\text {th }}$ Edition. New York: John Wiley \& Sons.

Suntharalingam, C., T.M.A.T. Ahmad, A.K. Ali, R. Rusli, N.A. Halim. 2011. Competitiveness of Malaysia's fruits in the global agricultural and selected export markets: Analyses of Revealed Comparative Advantage (RCA) and Comparative Export Performance (CEP). Economic and Technology Management Review. 6: 1-17.
Tambunan, T. 2000. Perdagangan Internasional dan Neraca Pembayaran: Teori dan Temuan Empiris. Jakarta: Pusat LP3ES.

Thamiem, S., J. Weerahewa, D.K.N.G. Pushpakumara, V.P. Singh. 2011. Trade Competitiveness of agroforestry crop sector in Sri Lanka. Tropical Agricultural Research. 22(4): 338-347.

Whitfield, L. 2012. Developing technological capabilities in agro-industry: Ghana's experience with fresh pineapple exports. The Journal of Development Studies. 48(3): 308-321. 